\title{
Private Ordering and the Creation of International Copyright Norms: The Role of Public Structuring
}

\author{
by
}

GRAEME B. DinWOODIE*

International copyright law must be based on an assessment of what types and levels of protection best further the purposes of copyright law. But constructing the international copyright regime is difficult as the international system must wrestle with copyright dilemmas that exist at the national level as well as broader challenges facing international law. This paper delineates the connection between international copyright law and the generation and distribution of knowledge by discussing two recent examples of (possible) unconventional international copyright rulemaking, namely, norms generated by Internet Service Providers in responding to infringement claims, and norms arising out of digital rights management systems (JEL: K 29).

\section{Introduction}

The generation and distribution of knowledge is conventionally identified as a central purpose of the grant of copyright protection. Copyright is an incentive that, properly calibrated, can positively affect the creation and availability of knowledge. In one sense, international copyright law might be understood as a mere spatial extension of that conventional proposition: if copyright contributes positively in some way to the knowledge supply in one country, the replication of this incentive dynamic in as many countries as possible will enhance the production and dissemination of knowledge worldwide. And the more knowledge, transferred to as many people as possible, the better.

Of course, even within single countries, the incentive argument can be pressed too simplistically. Intricate balancing of competing considerations is necessary to ensure that copyright does not undermine the public objectives that it purports to advance. Those institutions that develop international copyright rules must, no less than national lawmakers, pursue the same elusive goal of substantive balance. International copyright law must likewise be based on an assessment of what types and levels of protection best further the purposes of copyright law. But constructing the international copyright regime is doubly difficult, because the international system must wrestle not only with the

\footnotetext{
"Thanks to participants at the Conference on "The Generation and Distribution of Knowledge," Wienhausen, June 25-28, 2003, and in particular to Christian Kirchner, for comments on the draft paper presented.
} 
copyright dilemmas confronted on the national level but also with broader questions that international law encounters generally.

For example, what is the appropriate balance between universal rules and national autonomy? For many reasons, copyright owners have in recent years increasingly sought the adoption of an international rule earlier in the stage of norm development and with respect to a larger array of copyright issues (DINWOODIE [2000, pp.477-483]). In the digital world, the attraction of universal rules may be stronger for reasons of efficiency. But values of diversity and self-determination might counsel caution in moving too quickly in that direction. (AUSTIN [2001]). How does one construct an international rule that, by accommodating cultural and economic difference, maximizes social utility in different countries? Situated in the copyright context, these international law questions demand attention to the possibility that the incentives likely to maximize the generation and distribution of knowledge may vary widely from country to country. The international system must (and classically did) recognize that universality has costs, whether measured in economic or non-economic terms.

Over the past century, international copyright law has developed a set of concepts or methodologies that seeks to further the objectives of copyright law while taking into account these broader questions of international law. But international copyright norms are being developed in many new ways that might alter this accommodation. New institutional arrangements (both directly and through their effect on international copyright norms) may affect the generation and distribution of knowledge.

In this paper, I briefly sketch the connection between international copyright law and the generation and distribution of knowledge. I discuss two recent examples of (possible) international copyright norm formation that would fall outside a conventional understanding of international copyright law: (1) norms generated by the commercial practices of information intermediaries, internet service providers (ISPs), in responding to claims of alleged copyright infringement by their subscribers, and (2) norms arising from digital rights management systems (DRMs) employed by copyright owners to limit the ability of users of copyrighted works to engage in activity (e.g., fair use copying, or private copying where permitted by national legislation) previously authorized by public copyright laws. While conventional international copyright law has left much lawmaking in these areas to national law, in both contexts, international norms (both as regards substantive rules and structural allocation of norm-making between national and international levels) may be evolving with insufficient public scrutiny.

Both of these examples (most obviously, the latter) involve private ordering of social circumstances that affect the generation and distribution of knowledge. ${ }^{1}$ Particularly in the online context, private ordering has been hailed by some as an elixir to cure the inefficiencies of the offline world and to enhance the political legitimacy of governing rules and institutions. Yet, although private ordering has largely been validated in several areas of intellectual property law, its efficiency and legitimacy has been questioned in

\footnotetext{
${ }^{1}$ For a discussion of the different meanings of "private ordering," see ELKIN-KOREN [1998, pp. 1160f.]
} 
several domestic contexts, and the same will (and should) occur in the context of international copyright law.

Moreover, as in the domestic context, the legitimacy and success of private ordering will depend upon the legal underpinning of these nominally private transactions. These legal underpinnings, what I call the public structuring of private ordering, provide the points at which public values can most easily infuse and shape the regulation that private ordering effects. ${ }^{2}$ Moreover, as copyright owners over-reach, or imbalances favoring copyright owners arise, political pressure will increase to subject private ordering to greater public oversight. The two examples I discuss in this paper illustrate some of the possible mixes of private ordering and public structuring that we might consider. No single combination of private ordering and public regulation will be appropriate in all cases. However, to the extent that private ordering is effecting the creation of international copyright norms, public regulation must also be constructed with an eye to the issues and basic premises of international copyright law. ${ }^{3}$

\section{The Purposes and Basic Structure of International Copyright Law}

The dominant justification tendered for the existence of copyright protection is that it encourages the generation and distribution of knowledge (Mazer v. Stein 347 U.S. 201, 1954, LANDES AND POSNER [1989]). Copyright can be and is supported on other grounds (especially outside common law countries). (STEWART [1989], GOLDSTEIN, [2001]). And the precise dynamic by which copyright effectuates its knowledge-positive purpose is unclear: different groups of producers and distributors no doubt respond to a different balance of incentives, and the inter-relationship between incentives to produce and incentives to distribute is complex. But the incentive theory is given substantial weight in most countries throughout the world. (WIPO SURVEY [2002, p. 45]). At the very least,

\footnotetext{
${ }^{2}$ Justification for the elevation of public values may lie in the realist critique that public and private is an illusory divide. But it is at these points, where there is incontrovertible public structuring of the environment in which private ordering occurs, that the claim is easiest to sustain. The efficiency and the legitimacy of private ordering, and thus its ability to contribute to the development of international copyright norms, are intertwined with the public structuring.

${ }^{3}$ The use of norms developed through DRMs might more easily fit within most notions of private ordering than norms developed through the practices of ISPs. ISP norm-generating practice is incentivized by legislation that grants immunity in advance to certain practices; the ability of DRM systems to create copyright-inconsistent norms is ensured by legislation that, in response to the onset of DRMs, immunized the private acts of the content owner from being overridden by public values enshrined in the copyright law. But both raise the question of the extent to which, and means by which, norms generated through the practices of private actors and enforced by contract and technology should be subject to ongoing supervision to ensure that in certain circumstances publicly developed norms trump inconsistent privately generated arrangements. So I treat them together in this paper. Indeed, the ambiguities of the term merely highlight its truly mythical nature. See RADIN AND WAGNER [1998].
} 
there is a broad consensus that the content of copyright law is relevant to the supply of knowledge.

If, as conventional theory suggests, a certain level of copyright protection enhances the supply of knowledge, then extending this beneficent force to other countries through the development of an international copyright system will, inter alia, enhance the global store of knowledge. ${ }^{4}$ To be sure, other justifications for the development of the international copyright system abound. Recent development of international copyright law has also been supported by free trade philosophies, most notably that of comparative advantage. If one country has a comparative advantage in knowledge-based products, then global protection of intellectual property rights is essential to permit exploitation of that comparative advantage. Historically, adherents to natural rights theories of copyright could use the universalist character of natural rights to support international copyright laws. And historically-contingent explanations can be tendered for other developments in international copyright law. The TRIPS AgreEment [1994], (Agreement on TradeRelated Aspects of Intellectual Property Rights) for example, which contains a significant copyright component, can be seen as the product of a tradeoff in which developing countries received access to the markets of the developed world in return for enhanced levels of intellectual property protection (GERHART [2000b, pp.370-373]). At different times, different justifications have carried more weight. The international copyright system has, however, developed substantially since 1886, with the general goal of expanding geographically the store of, and access to, knowledge.

The international copyright system grew primarily from the conclusion of treaties among nation-states. These treaties typically were built around two basic concepts. First, signatory states had to provide in their domestic law certain minimum levels of intellectual property protection, so-called "substantive minima." The availability of property rights consistent with these norms would encourage local production of knowledge in the country newly acceding to the copyright regime. Second, as a general rule, signatory states were obliged to adhere to the principle of national treatment (i.e., offer protection to nationals of other signatory states that matched the protection each state afforded its own nationals). (Berne Convention for The Protection of Literary and Artistic Works, 1971 (Paris text), art. 5, 1161 U.N.T.S. 3). This principle, in tandem with substantive minima, ensured the availability of copyright protection in that country for foreign works and foreign authors. Under conventional theory, this combination would also enhance the access to works in the new country by encouraging foreign authors to expand their distribution to that country. (Moreover, the opening of new, secure markets

\footnotetext{
${ }^{4}$ In Eldred v. Ashcroft, 123 S. Ct. 769 (2003), the United States Supreme Court recently suggested that Congress could rationally view the development of the international copyright system, and the fullest U.S. participation therein, as a factor that could result in greater incentive for the creation and dissemination of works in the United States. This argument rests on more systemic concerns, namely, that anything that facilitates a more secure environment for the distribution of authors' work (which, in a digital era where works cross borders with ease, includes protection abroad) will encourage the generation and distribution of works. (PERLMUTTER [2002]).
} 
in turn might enhance the incentive offered to authors in all countries, further enhancing the global incentive to creation. (GERHART [2000b]).

In shaping these treaties, policymakers consider the access/incentive dynamic in ways not unfamiliar in the domestic copyright context. More incentive does not necessarily mean more production and distribution of knowledge. In some instances, gaps in protection lead not only to a reduced incentive but also to enhanced opportunities for creation and distribution. The argument for copyright protection relies on the increase in knowledge from enhanced incentive not being outweighed by a reduction in knowledgesupply that would otherwise occur through gaps in protection.

In the international context, and with respect to developing countries in particular, that calculation may be contingent on variables (e.g., disposable income, skills and investment necessary to develop indigenous industry) that differ substantially from conditions in the United States and that are not within the control of copyright law. ${ }^{5}$

Arguments for international copyright protection are thus strengthened by measures designed to ensure an indigenous economy that takes advantage of the enhanced incentive, and by the claim of developed countries that unauthorized works increasingly flow back to the developed country and undermine the knowledge-producing incentive system already in place there. These last two considerations are unique to the international context, but the basic access/incentive debate is a variant of the domestic policy discussion.

In treaties, however, signatory countries also had to grapple with broader questions that pervade international relations generally. These included, most importantly, the competing claims of universality and national autonomy or sovereignty. Every international instrument and institution implicitly addresses this question. The autonomy of nation-states in international copyright law serves the value of ensuring that states can tailor national laws to their own social and cultural demands. And it also serves to ensure that countries acted as laboratories in which to determine whether certain norms were superior to others as determinants of knowledge-supply. (DinwOODIE [2000], AUSTIN [2001]). Discussion of international copyright policy thus extends not only to substantive norms of copyright law, but also to whether certain norms should be allowed to evolve differently at the national level in lieu of articulating an international rule. ${ }^{6}$

The classical approach left states with substantial latitude in crafting their domestic copyright laws. Different countries situated in different social and economic conditions might optimize the production of knowledge through different calibration of the various

\footnotetext{
${ }^{5}$ The conventional argument prevails on the theory that authorized versions of works are likely in the long-term to be more numerous (or more reliably available) than the number of pirate copies that would be available in the second country in a copyright-free environment. The accuracy of this premise may vary between countries, differ as between different types of works, and be rendered quite unstable by the advent of digital communication technologies (especially as these technologies proliferate in lesser-developed countries).

${ }^{6}$ Those who see copyright as a natural right might be expected to argue for intrusive international norms with strong binding effect. Those who view copyright in more instrumental terms would likely prefer an approach that allowed each country, pursuing the same general objectives, to develop policies closely tied to a country's own social and economic conditions.
} 
doctrinal devices of copyright law. Latitude was achieved in several ways. The international system was paradoxically grounded in the principle of territoriality, despite the obligations for those national, territorial laws to comply with generally-stated international norms. The creation of a fixed, original work of authorship gives rise to separate national copyrights in all countries affording copyright protection according to the different national laws of each of those countries. There may be international copyright law, but there are no international copyrights. Moreover, the norms that member states were obliged to implement were stated merely as minimum levels of protection which member states could augment (but not derogate from), and these minimum standards were often quite undemanding. (DINWOODIE [2000, p. 491]). Indeed, in most instances, the treaty obligations reflected a consensus position that sought to codify existing state practice. (DINWOODIE [2000], p. 493). Many central concepts (such as who is an "author" of a copyrighted work) were expressly left open for signatory states to develop in accordance with their own national policies and values. Finally, because the obligations were not backed up with effective enforcement mechanisms, states were able to exploit that latitude with impunity. ${ }^{7}$

\section{Changes to the Structure of International Copyright Law}

These, then, were the structural or institutional norms that guided the development of international copyright law. In recent years, however, these institutional norms have been subjected to intense pressure to change. The pressures are largely the result of a pervasive feeling that international solutions are needed far more quickly in the copyright lawmaking process. Digital communication technologies and global trade are, of course, root causes of these pressures, though increasing resistance to certain copyright policies in the domestic political arena may have persuaded proponents of particular measures strategically to shift institutional focus to the international stage (where, to their dismay and surprise, the same competing forces are now arrayed). (SAMUELSON [1997]).

As a result of these pressures, we have seen numerous policymaking initiatives in an increased number of international forums (some of which had not previously addressed copyright law), giving rise to a burgeoning group of international norms. (GINSBURG [2000]). And to the extent that these norms have been incorporated in the TRIPS Agreement, they are enforceable through a dispute resolution system (that of the World Trade Organization) that has real teeth. The latitude for member state autonomy in both the formation and interpretation of international norms has been reduced, though it undoubtedly remains too early to make final judgments on the effect of the WTO system on international copyright law.

To some extent, many of these changes could have been predicted in 1994 when the TRIPS Agreement was concluded and when the ambitious EU legislative (and member state expansion) agenda was apparent. As momentum toward internationalization of

\footnotetext{
${ }^{7}$ Although provision was made in later revisions of the Berne Convention to refer disputes to the International Court of Justice, this was never done. [Berne Convention, art. 33].
} 
copyright law grew, it might not have been apparent, however, that this movement would still meet substantial resistance. ${ }^{8}$ Post-TRIPS, copyright policymakers encountered difficulty in reaching international consensus on a variety of new copyright issues. To be sure, the 1996 Internet Treaties (WIPO Copyright Treaty, WIPO Doc. CRNR/DC/94 (Dec. 20, 1996) 36 I.L.M. 65; WIPO Performances and Phonograms Treaty, (Dec. 23, 1996) 36 I.L.M. 76), are a notable exception, but even at that Diplomatic Conference one draft treaty was not discussed (the Database Treaty) and important issues relevant to copyright in the digital era (for example, service provider liability) were omitted from the adopted agreements. In this moment, it would seem that the international copyright system has paused to consider the effect of the TRIPS Agreement, the WTO dispute settlement system, EU harmonization and the Internet Treaties on the institutional environment. The prospects for new subject-specific treaties, let alone a broad-based TRIPS II, seem dim.

In this moment of reflection, other institutions have stepped forward. National (especially U.S.) courts have begun to offer interpretations of the scope of their national copyright laws that can easily extend their national copyright norms into international space, particularly in the online context. ${ }^{9}$ But when courts do so, at least nominally (if, to my mind, inadequately), they consider the international implications of their decisions under the rubric of private international law concerns of jurisdiction, applicable law, recognition of judgments, and comity. Other institutions have, however, begun to articulate and sub silentio develop international norms in ways that do not involve the conscious consideration of either the balance of copyright law or the additional concerns of international copyright law. The remainder of the paper discusses two such examples, but first situates them within the broader context of private ordering and copyright law.

\section{Private Ordering and Copyright Law}

Any rule of copyright law must encourage an optimal supply of knowledge in a vast array of different social and economic settings: copyright law covers a wide range of different works created and used in many different industries. Inevitably, default rules of copyright law are a blunt (and, some would say, inefficient) instrument for achieving an optimal level of protection. Private ordering might, by tailoring protection to particular settings and enabling price discrimination, make the creation and distribution of knowledge more efficient.

\footnotetext{
${ }^{8}$ See, e.g., WIPO MEMBERs FAIL tO Agree ON PERFORMERS' Rights FOR AUdio-VisuAL TREATY [2001]. Likewise, negotiations on a version of the draft Hague Agreement on Jurisdiction and Recognition of Judgments that broadly encompassed intellectual property reached an impasse, and the Database Treaty has sat on the WIPO shelf since 1996.

${ }^{9}$ See AUSTIN [2001, pp.1183ff.]; GEIST [2003, pp.335-339]. The phenomenon is even more pronounced in trademark law. See, e.g., Heathmount Corp. v. Technodome.com, 60 U.S.P.Q.2d (BNA) 2018 (E.D. Va. 2000); Sallen v. Corinthians, 273 F. 3d 14 (1st Cir. 2001); Harrods Limited v. Sixty Internet Domain Names, 302 F.3d 214 (4 ${ }^{\text {th }}$ Cir. 2002); see generally DiNWOODIE [2003].
} 
Private ordering of the treatment of copyrighted works has occurred through the use of both contract and technology. In the online context, contractual ordering has primarily taken the form of click-wrap contracts. Technological measures take private ordering further. Like click-wrap contracts, digital rights management systems (DRMs) enable price discrimination and tailored access rights. But they also hold out the prospect of selfenforcement, and there is not even the nominal involvement of the user in the negotiation of the terms of access.

Proponents of these forms of private ordering also claim efficiency gains that implicate international copyright principles. Online delivery of works is almost inevitably international in nature. Yet, the discordance between territorial copyright laws and the ubiquity of the internet presents immense problems of jurisdiction and applicable law which international copyright law has not yet resolved. Developing a system of conflict rules for copyright law is on the agenda of several institutions, but no solution is likely in the near future. (HAgUe CONFERENCE ON PRIVATE INTERNATIONAL LAW [2002]; American LAW Institute, Draft PRinciples [2003], WIPO Forum ON PRIVATE INTERNATIONAL LAW [2001]). In contrast, parties to a contract can agree to norms that are limited to a particular nation-state, or detached from any nation-state (e.g., the lex mercatoria applied by arbitrators in international commercial arbitration). Technology likewise can be programmed to permit access that corresponds to certain national norms, international norms, or to no existing norms at all. Both contract and technology are seen, therefore, as instruments to avoid not only the inefficiencies flowing from the bluntness of rules of copyright law, but also the uncertainties that impede the generation and distribution of knowledge in an international environment.

However, private ordering of the supply of knowledge through contract and technology has tended to result in a balance of rights and obligations more favorable to the content provider than would be the case under default rules of national copyright law. Thus, persons disadvantaged by this shift might be expected to argue for the over-riding application of copyright norms, notwithstanding the efficiency benefits that are claimed for private ordering. Such arguments can be grounded either in substantive concerns regarding the appropriate balance of rights, ${ }^{10}$ or in the uninclusive nature of the private "lawmaking process." Copyright law, notwithstanding public choice concerns that have made recent legislative activity unattractive to some scholars, is devised through a democratic system that confers a degree of legitimacy on the norms that are applied by courts. Private ordering lacks that legitimacy. Proponents of private ordering thus rest their claim of legitimacy on the nominally limited reach of that ordering, namely, the parties to the transaction. ${ }^{11}$

\footnotetext{
${ }^{10}$ This may, but need not, be entirely grounded in efficiency. It is an open question whether the efficiency gains of binding, technologically (largely) self-enforcing bargains outweighs the arguable efficiency costs of an imbalanced allocation of rights and privileges. But, even if there are efficiency gains, a variety of non-efficiency grounded values might support trumping private ordering (e.g., free speech, encouragement of heterodoxy, etc.).

${ }^{11}$ Putting aside for one moment the critique that such private activity (especially when replicated in the mass-market) impinges directly and indirectly upon non-parties to the transaction (i.e., the public), the notion that the private ordering is inclusively legitimate even inter partes is
} 


\section{Private Ordering and the Creation of International Copyright Norms}

Private ordering thus clearly has costs, and challenges to its displacement of copyright norms may yet succeed. ${ }^{12}$ But in other online intellectual property contexts, private ordering has become the means of (at least, initially) overcoming the jurisdictional and enforcement issues presented by the ubiquity of the internet. Most notable in this regard is the Uniform Domain Name Dispute Resolution Policy [1999], (the UDRP), adopted by ICANN in late 1999, which has become the international standard for resolving cybersquatting disputes through a powerful cocktail of contract and technology. (See Submission from Australia, COUNCIL FOR TRADE-RELATED ASPECTS OF Intellectual Property Rights [2000], Helfer And Dinwoodie [2001]). The UDRP shows that private actors may create "international law" with virtually as much ease (and certainly as much effect) as nation-states. The two examples discussed below suggest equivalent potential in copyright law.

\section{(a) Notice and Take-down Procedures}

The Digital Millennium Copyright Act 1998 introduced a set of provisions, now found in Section 512 of the Copyright Act, which created safe harbors for internet service providers alleged to have contributed to copyright infringement by subscribers. Among these safe harbors is one that enables an ISP to escape monetary relief for copyright infringement where it has hosted a subscriber's web site containing infringing material, provided that once the ISP receives a notice from a copyright owner reporting an alleged infringement it expeditiously takes down the infringing material and otherwise complies with the provisions of the notice and takedown procedure in Section 512.

Copyright owners are not obliged to use the notice and takedown procedures to pursue infringers. If they so desire, copyright owners may simply bring an infringement action against the user (and, contributorily, the ISP) under traditional principles of liability

fanciful in practice. Users that are parties to the transactions are largely as powerless to influence the terms of the deal as are the general non-party public.

${ }^{12}$ Challenges to private ordering that ousts copyright norms have, however, been unsuccessful, at least in the United States. The majority of challenges to click-wrap licenses (like challenges to shrink-wrap licenses previously) have failed, and the contractual terms have been allowed to prevail. (LEMLEY [1995]). There are exceptions, [Step-Saver Data v. Wyse Tec., 939 F.2d 91 (3d. Cir. 1991)], and recent case law is mixed, but the trend is still toward enforcement. [Bowers v. Baystate Technologies, 230 F.3d 1317 (Fed. Cir. 2003); Specht v. Netscape Comms., 306F.3d 14 (1st Cir. 2001)]. Most successful challenges have been grounded in contract doctrine, rather than insisting on the supremacy of copyright norms. [But see Vault Corp. v. Quaid Software, 847 F.2d 255 (5th Cir. 1988)]. Similarly, arguments that the norms of copyright law should be elevated over technological measures imposing restrictions inconsistent therewith have been rebuffed by the courts. [Universal City Studios v. Corley, 273 F.3d 419 (2d Cir. 2001)]. 
(which were not altered by the DMCA). But because the copyright owner may not know the user, and because the primary relief sought (the removal of the infringing material) can be achieved more cheaply and more quickly through the offices of the co-operating ISP than the offices of the courts, copyright owners have readily turned to the notice and take down procedure.

Likewise, ISPs are not obliged to comply with notices that they receive. ISPs may take the position that their subscriber's use is not infringing, or that they are not contributorily liable. But the immunity offered cooperating ISPs by Section 512 greatly incentivizes compliance; indeed, it incentivizes over-compliance (and little independent analysis) by ISPs that are in receipt of notices from copyright owners. ${ }^{13}$ (RIGHTS WATCH [2003], p. 5). Indeed, that is the value of the procedure, both to the copyright owner (who obtains complete co-operation) and the ISP (who is relieved of uncertainties over liability without any need to expend resources on making judgment calls or monitoring subscribers). As a result, takedown normally occurs within 24 hours. (DEPARTMENT OF TRADE AND INDUSTRY [2002], pp. 20 and 25).

Under the DCMA, ISPs in the United States have through their responses to notices under Section 512 effectively served as first-instance private adjudicators of infringement disputes between copyright owners and users who post copyrighted content to websites. ${ }^{14}$ But they are adjudicators who largely do not adjudicate; instead they process and enforce claims without consideration of the merits of the defendant's arguments.

Of course, the takedown notice is not the sum of the Section 512 procedure. In theory, these disputes are designed to precede litigation and the parties involved are always free to resort to judicial resolution. Thus, a subscriber who is informed that its ISP has received a notice of alleged copyright infringement may serve the ISP with a counternotification contesting the claim of infringement. The statute then incentivizes the ISP's restoration of the allegedly infringing material by granting the ISP immunity for complying with the restoration request (after informing the copyright owner, who may then initiate litigation, which will stay restoration). The first few years of practice under the statute, however, reveal that the overwhelming majority of disputes are resolved with

\footnotetext{
${ }^{13}$ The Rights Watch Report, which contemplates policies to be adopted in the EU, suggests that although ISPs might be incentivized to have scant regard for residential subscribers, that might not be true of a large corporation paying for dedicated hosting. This might in fact exacerbate concerns about this form of norm development, but there has been no evidence that ISPs operating under the DMCA have made this distinction. But if they had, it would be hard to detect, highlighting the need (discussed below) for transparency to be a guiding principle of any public structuring.

${ }^{14}$ See, INTERACTIVIST INFO EXCHANGE [2002]. Of course even in the offline context, different intermediaries (depending upon the type of work involved) often limit access to allegedly infringing work after receiving notice from the copyright owner. But in the online environment, ISPs become central actors in all copyright disputes, regardless of the type of work involved, and are thus able to determine the online availability of a broad spectrum of copyrighted works. The centrality of ISPs to the supply of knowledge online makes the ex ante structural incentives that will guide their conduct, and any ex post external checks, crucial.
} 
no counter-notification and no judicial intervention. (METALiTZ [2002], p 7; DEPARTMENT OF TRADE AND INDUSTRY [2002, p. 45]). ${ }^{15}$

The practices of ISPs are so central to the success of the notice and takedown procedure that they clearly have the capacity to develop norms both as regards the substantive scope of copyright protection and with respect to the enforcement of copyrights. The discussion above suggests that these practices are likely, because of incentives built into the DMCA, to shift the balance of rights toward copyright owners. But the DMCA does contain other provisions that are designed to balance the incentives that it creates to favor the copyright owner in the implementation of the notice and takedown procedure. In addition to ISP immunity for restoring material when requested to do so by a properly-served counter-notification, Section 512 provides civil liability for knowing material misrepresentations that cause unjustified removal of material (or unjustified restoration). These causes of action, plus the various immunities created by the statute, and an important provision that entitles copyright owners to obtain from ISPs the identity of the ISP's subscribers who are alleged to have engaged in copyright infringement by subpoena and without court order, are different elements ${ }^{16}$ of the "public structuring" of private ordering.

If the practices of ISPs were shown to be altering the scope of protection afforded copyright owners, what should policymakers do? Assuming that copyright law embodies a balance more likely to produce an optimal knowledge supply, policymakers would need to revise the elements of public structuring currently found in the Copyright Act. The fact that some might describe ISP-copyright owner practices as "private" transactions should be of no moment. Beyond the mythic qualities of the distinction that this presupposes, (RADIN AND WAGNER [1998]), the description of Section 512 above highlights that those practices are intensely structured and supported by public legislation, the Copyright Act.

For this to be achieved, however, the ISP-copyright owner practices have to be known. While the DMCA contains many elements of public structuring that suggest an effort to maintain a fair balance of rights, the practices that it engenders are not easily accessible to the public. The Copyright Office maintains no relevant records and does not monitor the notices. (DEPARTMENT OF TRADE AND IndUSTRY [2002], p. 24). At present, the practices are being monitored by non-governmental organizations (see CHILLING EFFECTS [2003]) and these forms of monitoring may ultimately cause governmental action. But transparency is lacking. ${ }^{17}$ Efforts to replicate the notice and take down procedure in the

\footnotetext{
${ }^{15}$ Of course, it might be argued that in most cases, the infringement is clear (see PERLMUTTER [2001], Comments p. 29)

${ }^{16}$ In order to make the notice and takedown procedure work efficiently, copyright owners also need reliable whois data. Again, the apparent private ordering of ISPs and copyright owners in fact requires substantial public underpinning.

${ }^{17}$ In this regard, although the UDRP system is lacking some of the structural design elements that inject balance into the notice and takedown procedure, such as a cause of action where complainants are found to have engaged in reverse domain name hijacking, the decisions of panelists are all public. This has enabled intense scrutiny, and has validated concerns that certain structural elements (such as the choice of dispute settlement provider being reserved exclusively to the trademark owner) skew the system.
} 
EU should tackle this important question, which will lend legitimacy to the procedures adopted. ${ }^{18}$

ISP practices under the DMCA may also be giving rise to an international copyright norm. At present, no multilateral treaty provisions expressly govern ISP liability. The Diplomatic Conference of the WIPO Copyright Treaty in 1996 did not adopt any provision regulating service provider liability (though countries did adopt an Agreed Statement accompanying Article 8, which required states to offer copyright owners the exclusive right to make a work available to the public, acknowledging that "the mere provision of physical facilities for enabling or making a communication does not in itself amount to communication within the meaning of this Treaty or the Berne Convention.”). Yet this is a topic that cries out for international agreement, or cooperation. (PERLMUTTER [2001, p. 28]) WIPO has tried to encourage convergence of standards through workshops on ISP liability, (WIPO WORKSHOP [1999]), and intellectual property owners in the United States are lobbying hard for other countries to adopt the DMCA model (DEPARTMENT OF TRADE AND INDUSTRY [2002, p. 20]).

And, in fact, ISP practices under the DMCA are coming to establish the international norm. U.S. copyright owners are serving notices on ISPs worldwide under Section 512, (METALITZ [2002, p.8]), and receiving surprisingly high levels of compliance. (GEIST [2003; p.377]). To be sure, discrete (though similar) practices continue to evolve in other countries, and this is not the first occasion when the law of a single country has purported to have broad territorial reach. As noted above, although national courts nominally apply their intellectual property laws territorially, U.S. courts have applied their copyright and trademark law in a fashion that has arguably made U.S. law the dominant law online. But, there, the extended reach of U.S. law has occurred through its public application by courts, nominally restrained by rules of private international law, a context that is both apparent and subject to contest by courts of other countries. As those rules codify through the public debate that the decisions themselves generate, one would expect a more diverse range of prescriptive influences. (Yahoo! Inc.v. Le Ligue Contre Le Racism et L'Antismitisme, 169 F. Supp.2d 1181 (N.D. Cal.2001); Globalsantafe Corp. v. Globalsantafe.com, 250 F. Supp.2d 610 (E.D. Va. 2003); America Online Inc. v. AOL.org, 259 F. Supp.2d 449 (E.D. Va. 2003)).

ISP practices under the DMCA might, in addition, shift the balance between the application of national and international rules, a shift which is itself construction of a new

\footnotetext{
${ }^{18}$ Member States of the European Union are still considering how to implement a similar notice and takedown system. Article 14 of the E-Commerce Directive obliged member states to enact a similar immunity from liability as Section 512, but contained significantly less detail. The recitals to the Directive instruct member states to encourage the development of a notice and take-down system by means of "voluntary agreement between all parties concerned." [Recitals 40-46]. In constructing the agreements, member states should be alert not only to the elements of public structuring in Section 512, but also to the demand for transparency. Lawmaking by private agreements always raises concerns of voice and legitimacy. This is particularly likely to be so where there is no mechanism to publicize or monitor the application of these rules. The EU "voluntary agreements" must take these transparency concerns into account, because the directive itself makes no such provision.
} 
international copyright norm. As noted above, an implicit element in every aspect of the international copyright regime is the allocation of prescriptive authority to national or international institutions. Where this balance is adjusted via ISP practices, however, the allocation between national and international sources will likely not occur through a conscious decision that certain values require for reasons of efficiency, already existing harmonization, or the maintenance of divergent and fundamental national values, to be set at one level or the other. Instead, this allocation might be the product of such serendipitous forces as the governance structure of multinational ISPs or the market for ISP services (itself potentially the subject of regulation) or the geographic composition of an ISP's subscribers (which may be affected by any number of variables).

Alternatively, and still speculatively, the balance of national and international norms could be altered by a contractually grounded extension of the UDRP model into the copyright realm. If ISPs acquire customers from several different countries, ISPs might wish to establish a single policy for responding to alleged acts of copyright infringement. Indeed, because ISPs may (acting collectively) offer a choke point not unlike that made available in the domain name context by ICANN's control of the root server, one might envision a system that sought to expose a larger number of these copyright complaints to the light of day and provide some form of adjudication of their merits. An ISP could contractually require subscribers to submit to dispute settlement of infringement claims by third-party copyright owners with respect to postings of copyrighted materials on the ISP's servers. The dispute settlement providers could, like the panelists in the UDRP context, be authorized to apply some designated body of rules, be they national or international copyright laws or some hybrid, to determine whether the ISP must remove such allegedly infringing materials.

In such an event, the rules applicable to notice and take down disputes may well evolve away from purely national roots toward contract-enshrined norms and practices not tied to any particular prescriptive authority. Such rules may evolve quite independently of the norms of any particular nation-state. If such a system were to develop, ${ }^{19}$ it would even more directly raise the challenges of private ordering: rights of users coercively (though, nominally, contractually) subjected to adjudication before forums of private adjudication. ${ }^{20}$

Whether non-national or international norms develop by dint of practice or through a contractually constructed system, it is important to remember the role of public structuring. This is not to deny the benefits of dynamic, non-national specific standards that such a system might embody, or the efficiency gains that are generated by fast

\footnotetext{
${ }^{19}$ Copyright owners are content with the current system and would be unlikely to agree to any such experiment, which they would view as unnecessary and blind to the benefits of an automatic process that deals quickly and cheaply with routine cases of piracy. Moreover, they would argue, users already have the capacity to force content owners to court in order to vindicate their claim. These arguments are most easily rebutted, of course, if over-reaching by copyright owners is shown.

${ }^{20}$ As in the case of the UDRP, one could not imagine national courts deferring to such decisions simply because they are the product of institutions established by private arrangement and "affect only" those private parties.
} 
processing of routine complaints. Rather, for the benefits of these rules not to be outweighed by corresponding costs, any procedural mechanism that is established must address not only the substance of the norms, but the structural incentives for their application in one direction or another, and the publicizing of the practices in ways that facilitate active national legislative or judicial involvement if that is appropriate. Moreover, there must be a public-oriented input toward the allocation of certain issues to the national, and other issues to the international, realm.

\section{(b) Agreements contemplated by Article 6(4) of the EU Copyright Directive}

The EU E-Commerce directive contemplates agreements among right-holders, contentproviders and users regarding notice and takedown procedures (Directive 2000/31/EC of the European Parliament and of the Council of 8 June 2000 on certain legal aspects of information society services, in particular electronic commerce, in the Internal Market, O.J. L 178, 1, 12-13). But, while that directive contains no mandatory review of those agreements, the more recent EU Copyright Directive goes further (procedurally, if not substantively) in acknowledging that private ordering should be subject to publiclydefined limits. The Directive (in Article 6) implements Articles 11 and 12 of the WIPO Copyright Treaty, which obliged signatory countries to protect effective technological measures (i.e., DRMs) against unauthorized circumvention. (The treaties still left national law much room for experimentation. SAMUELSON [1999, pp. 530-533]). Like the DMCA, the Copyright Directive validates DRMs as a form of private ordering. Like ISP practices in response to notices from copyright owners, technology need not be nationally configured. Technology is not inherently territorial, and thus to the extent that national laws validate DRMs that are not tied to national copyright rules, they may (if the DRMs are replicated by content owners generally) be validating international norms. Indeed, it may add expense (but enable greater price discrimination) to make the terms of use or access country-specific.

Alternatively, geographically-oriented technological measures have the capability to reterritorialize international knowledge markets in ways that bring product distribution back to the historical premises of international copyright law, rather than reconfigure copyright norms to the basis of contemporary product distribution. Region-coding of DVDs exemplifies this option. ${ }^{21}$ Thus, decisions made in the construction of DRMs by content owners may determine whether norms of access to works are set nationally or internationally. And, as suggested above, they have the capacity to set norms without reference to the balance of rights established in copyright law (whether national or international). Private ordering thus, once more, can affect the structural norms of

\footnotetext{
${ }^{21}$ In the draft Finnish implementation of the Copyright Directive, region-coding of DVDs is expressly excluded from the definition of "technological measure," thus enabling the sale of devices that circumvent region-coding. Region-coding clearly limits the ability of the technological protection measure to establish international norms.
} 
international copyright law: according to which set of values will the decision whether to universalize or territorialize be made?

This discussion, of course, assumes wholesale validation of private ordering. But the legislative inclination thus far does appear to be in favor of DRMs effecting norms regarding the distribution of knowledge, whether inconsistent with national copyright law (though some limited exemptions patrol that boundary) and whether inconsistent with international copyright norms (concerning which no legislative intent can be discerned).

The EU recognized the potential problem of unbalanced private ordering, and the possibility that an unduly strict application of the new quasi-copyright prohibition may have the effect of denying users the right to engage in acts that would otherwise be permitted by copyright law. To redress any imbalance, Article 6(4) of the Copyright Directive relies in the first instance on "voluntary measures taken by the right-holders, including agreements between right-holders and other parties concerned" to ensure that beneficiaries of exceptions are able to exercise those exceptions. ${ }^{22}$ Thus, it seeks to ensure that certain ${ }^{23}$ copyright values will be preserved notwithstanding technological protection measures inconsistent therewith. ${ }^{24}$

Moreover, if such measures are not taken voluntarily, Article 6(4) of the Directive provides that "Member States shall take appropriate measures to ensure that right-holders

\footnotetext{
${ }^{22}$ See Article 6(4). The only type of "voluntary measure" expressly referenced in Article 6(4) is "agreements between right holders and other parties concerned." But reaching such agreements will be a difficult task. As the range of stakeholders with interests implicated by copyright law expands, reaching consensus becomes difficult (even assuming you can identify the stakeholders). Indeed, because some of the exceptions at issue are linked to certain types of uses and not defined categories of users (i.e., are purpose exceptions, not identity exceptions), the beneficiaries may be quite diverse. Thus to the extent that private contractual arrangements among interested parties will be the means by which the ability to take advantage of copyright exceptions is guaranteed, there will likely have to be a complex web of agreements. Of course, agreements are not the exclusive form of "voluntary measure," so right-holders might also consider modification of technological measures in ways that enable beneficiaries to take advantage of the exceptions in question.

${ }^{23}$ Article 6(4) only applies to certain stated exceptions, and only in so far as those exceptions are recognized in the national copyright law in question.

${ }^{24}$ The Copyright Directive also regulates the relationship between compensation rights of authors under "private copying" schemes in national copyright laws and the use of technological protection measures. Article 5 provides that the appropriate rate of return for authors under such compensation schemes should take into account the extent to which technological protection measures have been deployed. Indeed, a recital to the directive contemplates that the compensation under the copyright scheme might be reduced to zero where technological protection measures enable the author to obtain payment. But this provision only minimally regulates the technological protection measures: it does not make the copyright norm prevail, but rather simply ensures that the public system does not duplicate payments already extracted by private ordering. The payment extracted by private ordering may, however, exceed the payment that would have been available under the public system. Thus, as discussed below, article 6(4) may be closer to a mechanism that ensures the predominance of the default norms of copyright law.
} 
make available to the beneficiary [ ... ] the means of benefiting from" certain exceptions and limitations to copyright. ${ }^{25}$ Thus, unlike the agreements contemplated by the ECommerce Directive, here there is a shadow in which the bargaining will take place. Substantively, it is a narrow shadow: only a very few exceptions and limitations are listed (and this is a major failing as a public structuring control element). But procedurally, it presents great latitude to member states.

What are appropriate measures that member states might adopt under Article 6(4)? Different member states are (in their current proposals) experimenting with different mechanisms. These differ in several respects, but most importantly, they vary in terms of institutional allocation of authority among courts, magistrates, and the administrative and legislative branches. (FOUNDATION FOR INFORMATION POLICY RESEARCH, [2003, pp. 24125]). If these differences persist in the final implementing legislation, then we may be presented with a series of experiments on how best to control and monitor private ordering in ways that preserve the benefit of DRMs without conceding control on the important public question of how to ensure a balance of rights between copyright owners and users.

If the inconsistency of DRMs with national copyright law is resolved by initial agreement between right-holders and the beneficiaries of exemptions, there is a possibility that the DRMs might seek to impose the same technological protection measures on products distributed internationally, raising the prospect that the DRMs (as modified by agreements between interested parties) will come to create international norms. ${ }^{26}$ This is likely, at least within the European Union. Whether such norm-creation by a mix of technology and contract should have a broader geographical remit should ideally be determined by the set of structural international copyright norms that guided the historical balance (contemporarily interpreted) between national autonomy and universality. More likely, it will be determined by whether, within industry groups, there is the political will to extend any agreement reached within the European Union to the United States and elsewhere. Article 6(4) is a creditable (if overly limited and undefined) effort at imposing public checks on private ordering. But the values of the international copyright system, with their attendant affects on the generation and distribution of knowledge, are noticeably absent.

\section{The Role for Public Structuring and International Norms}

\footnotetext{
${ }^{25}$ The proposed German implementation of the Copyright Directive contains an interesting provision that reflects comments above regarding transparency. Private ordering proponents frequently assert that any imbalance that occurs can be corrected by the competitive market; consumers will not buy goods protected by oppressive DRMs. But the market is constructed on massive information asymmetry. Germany proposes to partially correct that asymmetry by public regulation, namely, by requiring any work protected by DRM to be labeled in a fashion that discloses the restrictions on its use. FOUNDATION FOR INFORMATION POLICY RESEARCH, [2003].

${ }^{26}$ If ensuring compliance with exceptions available under national law falls to the safeguard mechanisms contemplated by Article 6(4), it is more likely that any solution will be tied to national norms.
} 
As both of these examples demonstrate, private ordering has (as its proponents have argued) substantial ability to overcome the persistent problem of territorial rights in a less than fully territorial world. Yet, both are ultimately dependent upon an underpinning of public regulation, even if that regulation consists of a decision to forbear from acting. The mix of public structuring that will be essential to buttress effective private ordering will vary from one context to another. In some, it will be forbearance from intrusive regulation; in others it will be laws supplying the instruments (e.g., subpoena power to obtain information about alleged infringers) by which parties are able to engage in efficacious private ordering; and in yet others, it will consist in a set of related liabilities (or immunity therefrom) that incentivize private conduct.

It is clear that private ordering is dependent upon public structuring for its effectiveness. The central political question, however, that is essential to the legitimacy of publicly-structured private ordering is that the forms of structuring are sufficiently balanced to ensure that the outcomes produce - when implemented through private ordering - a balance of rights and access that furthers the optimal supply of knowledge. For those who are skeptical of the wholly "private" nature of any social activity, it is not difficult to justify conscious political choices surrounding the nature of the public structuring. But even for those who attach the ("do not disturb") label of "private" to what ISPs do in response to notices from copyright owners, or what content owners do in implementing DRMs, it is surely evident that their favored system is heavily dependent upon public structuring, and thus not immune from the public oversight that is appropriate in return for public support. ${ }^{27}$

Even with conscious attention to the nature of that public structuring, because some of the ways that the private ordering will play out will likely flow from such unpredictable forces as the organizational structure of firms and inter-industry political bargains, it will be important for public structuring to be prospective and dynamic (no less than copyright law itself must be able to react to change). The provisions in Article 6(4) of the EU Copyright Directive, if expanded in scope, appear to possess that potential, even if in the Directive they assume only abstract form. And for such assessment to be made on an ongoing basis, whatever private ordering occurs must be subjected to the light of day. This can be done by non-governmental organizations, but more importantly such transparency must itself be built into the public structuring of the private system. If open government is a mantra of liberal democratic polities, then transparent private ordering

\footnotetext{
${ }^{27}$ In offline contexts, rarely was the availability of content of all types at the mercy of a single group of technological providers. Certainly, distribution channels for particular types of works contained dominant market players; the mass availability of hard copy books offline is increasingly (in the United States) a function of the availability of Barnes \& Noble and Borders. And the availability of performance licenses for musical works was heavily dependent upon the practices of ASCAP and BMI. But these institutions acted subject to legal restraints (e.g., antitrust laws) rather than under the protection of legal immunities. This is public structuring in the offline world that was effective, and important. If copyright owners asserted egregious over-reaching, possible causes of action did exist (whether constructed creatively or expressly sanctioned, as is the case in the UK). (HEALD [1994]).
} 
must equally be the obligation of those who purport (beneficently) to arrive at the same results through private governance.

Finally, each of these forms of private ordering has the potential to create international norms, both substantively, and structurally in the allocation of certain norms to the national or international level. Yet, no public structuring that currently exists holds private lawmakers to account for their decision to alter the balance of national autonomy and universal rules. International copyright law embodies important structural or institutional norms that impinge directly upon the generation and distribution of knowledge: national autonomy, diversity of values, and resistance to orthodoxy, are all valuables tools in optimizing the knowledge supply. Public structuring that fails to account for these international values has failed to account for an important part of a system that purports positively to affect the creation and availability of knowledge.

\section{References}

AMERICAN LAW INSTITUTE [2003], Draft Principles on Jurisdiction and Recognition of Judgments in Intellectual Property Matters, Preliminary Draft No. 1, Philadelphia, (Jan. 17, 2003).

Austin, G. W. [2001], “Valuing Domestic Self-Determination in International Intellectual Property Jurisprudence,” Chicago-Kent Law Review, 77, 1155-1211.

CHILLING EFFECTS [2003], online internet, www.chillingeffects.org.

COUNCIL FOR TRAde-Related AsPects of Intellectual Prop. Rights, WTO, Electronic Commerce Work Programme: Submission from Australia, Doc. No. IP/C/W/233 (Dec. 7, 2000), online internet, http://docsonline.wto.org/DDFDocuments/t/IP/C/W233.doc.

DEPARTMENT OF TRADE AND INDUSTRY [2002], “Combating Internet Copyright Crime.” The Publishers Association [2002], London, online internet, http://www.publishers.org.uk/

Dinwoodie, G. B. [2000], “A New Copyright Order: Why National Courts should Create Global Norms,” University of Pennsylvania Law Review, 149, 469-580.

- [2003], “The Extended Reach of the ACPA: The Domination of Trademark Rights or the Domination of U.S. Law,” Paper Presented to Eleventh Annual Fordham Conference on International Intellectual Property Law and Policy, New York, (Apr. 24)

ELKIN-KoRen, N. [1998], “Copyrights in Cyberspace Rights Without Laws?,” ChicagoKent Law Review, 73, 1155-1201.

FOUNDATION FOR INFORMATION POLICY RESEARCH [2003], Implementing the EU Copyright Directive, Cambridge, (Sept. 2003)

GeIst, M. [2003], “Cyberlaw 2.0", Boston College Law Review, 44, 323-358.

GerharT, P. [2000a], "Reflections Beyond Compliance Theory: TRIPS as a Substantive Issue, Case Western Reserve Journal of International Law, 32, 357-385.

- - [2000b], "Why Lawmaking for Global Intellectual Property is Unbalanced,” European Intellectual Property Review, 22, 309-312. 
GinsBurG, J. C. [2000], ““'n International Copyright: From a Bundle of National Copyright Laws to a Supranational Code,“ Journal of Copyright Society, 47, 265-290. Goldstein, P. [2001], “International Copyright”, Oxford University Press, New York.

Hague Conference ON PRIVATE InTERnAtional LAW [2002], Summary of the Outcome of Discussions in Commission II of the First Part of the Diplomatic Conference, June 6-20, 2001, Chicago-Kent Law Review, 75, 1015-1064.

HeALD, P. J. [1994], "Payment Demands for Spurious Copyrights: Four Causes of Action,” Journal of Intellectual Property Law Journal, 1, 259-282.

Helfer, L. R., AND G. B. Dinwoodie [2001], "Designing Non-National Systems: The Case of the Uniform Domain Name Dispute Resolution Policy," William \& Mary Law Review, 43, 141-274.

INTERACTIVIST INFO EXCHANGE [2002], “Activist Network in New York City Evicted from Internet by Dow, Verio”, online, internet, (Dec. 23, 2002). http://slash.autonomedia.org/article.pl?sid=02/12/23/153204

LANDES, W., AND R. Posner [1989], “An Economic Analysis of Copyright,” Journal of Legal Studies, 18, 325-363.

Lemley, M. A. [1995], "Intellectual Property and Shrink-wrap Licenses," Southern California Law Review, 68, 1239-1294.

Metalitz, S. J. [2002], "Implementation of the DMCA: The Practical Experience", Working paper, Ninth Annual Conference on International Intellectual Property Law and Policy, (Apr.20).

Perlmutter, S. [2002], "Participation in the International Copyright System as a Means to Promote the Progress of Science and the Useful Arts," Loyola Law Review, 36, 323-335.

- -[2001], Comments from SOFTIC Conference, $10^{\text {th }}$ Softic International Symposium, Tokyo

Radin, M. J., AND R. P. WAgner [1998], "The Myth of Private Ordering: Rediscovering Legal Realism in Cyberspace,” Chicago-Kent Law Review, 73, 1295-1317.

Rights WATCH [2003], “Final Project Report”, Information Society Technology Programme, (Nov. 2002-Jan. 2003).

SAMUELSON, P. [1997], “The U.S. Digital Agenda at WIPO,” Virginia Journal of International Law ,37, 369-439.

- -[1999], "Intellectual Property and the Digital Economy: Why the Anti-circumvention Regulations Need to be Revised,” Berkeley Technology Law Journal, 14, 519-566.

STEWART, S. [1989], International Copyright and Neighboring Rights (2d ed).

Uniform Domain Name Dispute Resolution Policy (Oct. 24, 1999), at http://www. icann.org/udrp/udrp-policy-24oct99.htm.

Trips Agreement [1994], Agreement on Trade-Related Aspects of Intellectual Property Rights, Apr. 15, 1994, WTO Agreement, Annex 1C, Legal Instruments-Results of the Uruguay Round, vol. 31, 33 I.L.M. 81.

Uniform DOMAin NAME DisPUTE RESOlution POLICY [1999], at http://www.icann.org/ udrp/udrp-schedule.htm.

WIPO Members Fail to Agree on Performers Rights for Audio-Visual Treaty [2001], Patent, Trademark \& Copyright Journal, 61, 231, January 5. 
WIPO Workshop on Service Provider Liability, [1999], Dec. 9-10, Geneva, papers available at http://www.wipo.org/eng/meetings/1999/osp/

World Intellectual Property Organization [2002], Intellectual Property on the Internet: A Survey of Issues, WIPO Doc. No. WIPO/INT/02 (Dec. 2002).

World InTEllectual Property Organization, Forum on Private International Law (Jan. 2001), www.wipo.int/pil-forum/en/

\author{
Graeme B. Dinwoodie \\ Chicago-Kent College of Law \\ 565 West Adams \\ Chicago, IL 60661-3691 \\ USA \\ E-Mail: \\ Gdinwoodie@kentlaw.edu
}

